\title{
NEOČEKIVANO OTEŽANA INTUBACIJA
}

\section{UNEXPECTEDLY DIFFICULT AIRWAY}

\author{
Danijela Stanković (1), Zoran Jovanović (1), Siniša Čelojević (2),Tihomir Milovanović (3) Biljana Stošić (4)
}

(1) SLUŽBA ANESTEZIJE I REANIMACIJE, ZDRAVSTVENI CENTAR NEGOTIN; (2) ODELJENJE GINEKOLOGIJE I AKUŠERSTVA, ZDRAVSTVENI CENTAR NEGOTIN, (3) ODELJENJE ORTOPEDSKE HIRURGIJE I TRAUMATOLOGIJE, ZDRAVSTVENI CENTAR NEGOTIN, (4) CENTAR ZA ANESTEZIOLOGIJU I REANIMATOLOGIJU, KLINIČKI CENTAR NIŠ

Sažetak: UVOD: Otežani disajni put se definiše kao: „klinička situacija u kojoj iskusni anesteziolog ima poteškoće pri ventilaciji pacijenta facijalnom maskom, poteškoće pri trahealnoj intubaciji, ili oba." Procena disajnog puta predstavlja jedan od prvih i ključnih koraka anesteziološkog preoperativnog pregleda i određuje strategiju u planiranju položaja pacijenata, opreme, tehnika i lekova. Postoje prediktori otežanog disajnog puta: gojaznost, deformiteti vilice i vrata, makroglosija, mali interincizorni razmak, prominentni grudni koš, velike grudi, mala tireomentalna distanca. Najčešće se koristi Mallampati klasifikacija, gde su klasa 3 i 4 prediktori otežane intubacije. Najkorisnija je kombinacija testova, ne postoji idealan prediktor za procenu otežanog disajnog puta, neočekivano otežane intubacije se u praksi dešavaju s vremena na vreme. Cilj rada je prikazati slučaj neanticipirano otežane intubacije, analizu postupaka i preduzetih mera. MATERIJAL I METODE: Deskriptivna metoda, podaci iz anestezioloških karti. PRIKAZ SLUČAJA: Pacijentkinja stara 62 godine, mase $50 \mathrm{~kg}$ i visine $160 \mathrm{~cm}$, se priprema za planiranu operaciju, sa uputnom dijagnozom: Tumor ovarii dextri per magna. Bez značajnih je komorbiditeta. U proceni disajnog puta ima zadovoljavajuću pokretljivost vrata, tireomentalnu distancu, Mallampati 2, nije gojazna, jedino je interincizorni razmak graničnih vrednosti od oko $3 \mathrm{~cm}$. Ne anticipira se mogućnost za otežanu intubaciju. Posle premedikacije, pacijentkinja se pozicionira u horizontalni položaj. Nakon uvoda u anesteziju, ventilacija facijalnom maskom je zadovoljavajuća. Posle aplikovanog kratkodelujućeg depolarišućeg miorelaksanta pristupa se laringoskopiji. Uočava se veliki epiglotis koji je nemoguće podići, te su plicae vocalis nedostupne vizualizaciji. Endotrahealna intubacija je pokušana u 3 navrata. Nakon neuspeha, plasira se supraglotično sredstvo- laringealna maska. Laringealna maska se ne pozicionira zadovoljavajuće, ne postiže se korektna ventilacija. Zbog insuflacije vazduha u želudac i nezadovoljavajuće ventilacije, donosi se odluka o odlaganju operativnog zahvata za nekoliko dana. Pacijentkinja se budi, diše spontano. Svi podaci, sa detaljnim opisom su zabeleženi u anesteziološku kartu. Suočen sa neanticipirano otežanom intubacijom, anesteziološki tim se detaljno priprema za odloženi operativni zahvat i menja strategiju za obezbeđenje disajnog puta. Pacijentkinja se smešta u antiTrendeleburg položaj, glava se elevira, ravna se osovina gornjih disajnih puteva i omogućava bolja vizualizacija anatomskih struktura. Jedan anesteziolog pristupa laringoskopiji, a drugi BURP manevrom (Backward, Upward, Rightward Pressure), intubatoru približava strukture larinksa, omogućava vizualizaciju i uspešnu intubaciju. Diskusija i zaključak: Vodič Asocijacije za otežani disajni put iz 2015. godine akcenat stavlja na pažljivo planiranje i detaljno upoznavanje celokupnog tima sa strategijom obezbeđenja disajnog puta. Pozicioniranje glave i vrata mora biti optimizirano u samom startu, da bi prvi pokušaj intubacije bio uspešan. Oprema za otežanu intubaciju mora biti lako dostupna. Sve poteškoće detaljno zabeležiti u medicinsku dokumentaciju, što je od ogromnog značaja za anesteziologa i pacijenta pri eventualnom sledećem operativnom zahvatu.

Ključne reči: otežana intubacija, vodič, strategija

Summary: Introduction: Difficult airway is defined as "clinical situation where an experienced anesthesiologist has difficulty in ventilation patient's facial mask, difficulty in tracheal intubation, or both." The assessment of the airway is one of the first and key step in anesthetist preoperative examination, and determined strategy to plan positioning of patients, equipment, technology and medicine. There are few 
difficult airway predictors: obesity, deformities of the jaw and neck, macroglossia, interincisor small space, prominent chest, large breasts, small tireomental distance. The most commonly used Mallampati, wherein the class 3 and 4 predictors of difficult intubation. The most useful is a combination of tests, there is no perfect predictor for assessing airway difficulties, unexpected difficult intubation in practice occur from time to time. Objective: Case report of unanticipated difficult intubation, analysis procedures and measures taken. Materials and method: A descriptive method, the data from the anesthetic records. Case report: A 62 year old female patient, weighing $50 \mathrm{~kg}$ and a height of $160 \mathrm{~cm}$, is preparing for the planned operation, with the diagnosis: Tumor ovarii dextri per magna. Without significant comorbidity. In assessing the airway, patient had sufficient mobility of the neck, tireomental distance, Mallampati class 2, not obese, only interincisor space limits of about $3 \mathrm{~cm}$. The possibility for difficult intubation is not anticipated. After premedication, the patient is positioned in a horizontal position. After the introduction of anesthesia, ventilation facial mask was good. After aplication short acting depolarizing muscle relaxants, access to laryngoscopy. It is observed that a large epiglottis is impossible to raise, and plicae vocalis were unavailable for visualization. Endotracheal intubation was attempted in 3 times. After the failure, the supraglottic device laryngeal mask was placed.Laryngeal mask was not positioned satisfactorily to achiev the correct ventilation. Because insufflation of air in the stomach and unsatisfactory ventilation, we made a decision to postpone the surgery for a few days. The patient wakes up, breathe spontaneously. All data, with detailed descriptions were recorded in the anesthetic card. Confronted with the unanticipated difficult intubation, anesthetic team is thoroughly prepared for delayed surgery, and changes the strategy for airway management. The patient is placed in the antiTrendeleburg position, the head is elevated, thus the axes of the upper airway and allows a better visualization of anatomical structures. One anesthesiologist approach to direct laryngoscopy, and other performed BURP maneuver (Backward, Upward, Rightward Pressure), approaching structures of the larynx, and allows visualization of the successful intubation. Discussion and conclusion: The Guide Association for difficult airway from 2015 emphasis on careful planning and detailed knowledge of the entire team with the strategy of securing the airway. The positioning of the head and neck must be optimized from the start to make the first intubation attempt successful. Equipment for difficult intubation must be easily accessible. All the difficulties must be detaily noted in the medical records, which is of great importance for the anesthesiologist and patient with possible following surgery.

Kew words: difficult intubation, guideline, strategy

UVOD

Otežani disajni put se definiše kao: " klinička situacija u kojoj iskusni anesteziolog ima poteškoće pri ventilaciji pacijenta facijalnom maskom, poteškoće pri trahealnoj intubaciji, ili oba“ (1). Pre izvođenja anestezije, anesteziolog bi trebalo da bude u stanju da sebi odgovori na sledeća pitanja: pacijenta? Hoću li biti u stanju da ventiliram

Hoću li biti u stanju da izvedem laringoskopiju, direktnu ili indirektnu? Hoću li biti u stanju da intubiram pacijenta?

Postoji li značajan rizik od aspiracije?

Ako sam predvideo teškoće $u$ obezbeđenju disajnog puta, da li bi trebalo da osiguram disajni put budnom pacijentu?

Da li mi je dostupna krikotiroidna membrana, ukoliko je potrebno izvesti krikotiroidektomiju? ekstubacije?

Kako će se ponašati disajni put tokom

Procena disajnog puta predstavlja jedan od prvih i ključnih koraka anesteziološkog preoperativnog pregleda, i određuje strategiju u planiranju položaja pacijenata, opreme, tehnika i lekova. Postoje prediktori otežanog disajnog puta: gojaznost, deformiteti vilice i vrata, makroglosija, mali interincizorni razmak, prominentni grudni koš, velike grudi, mala tireomentalna distanca. Najčešće se koristi Mallampati klasifikacija, gde su klasa 3 i 4 prediktori otežane intubacije. (Slika 1.) 
Slika 1. Mallampati klasifikacija

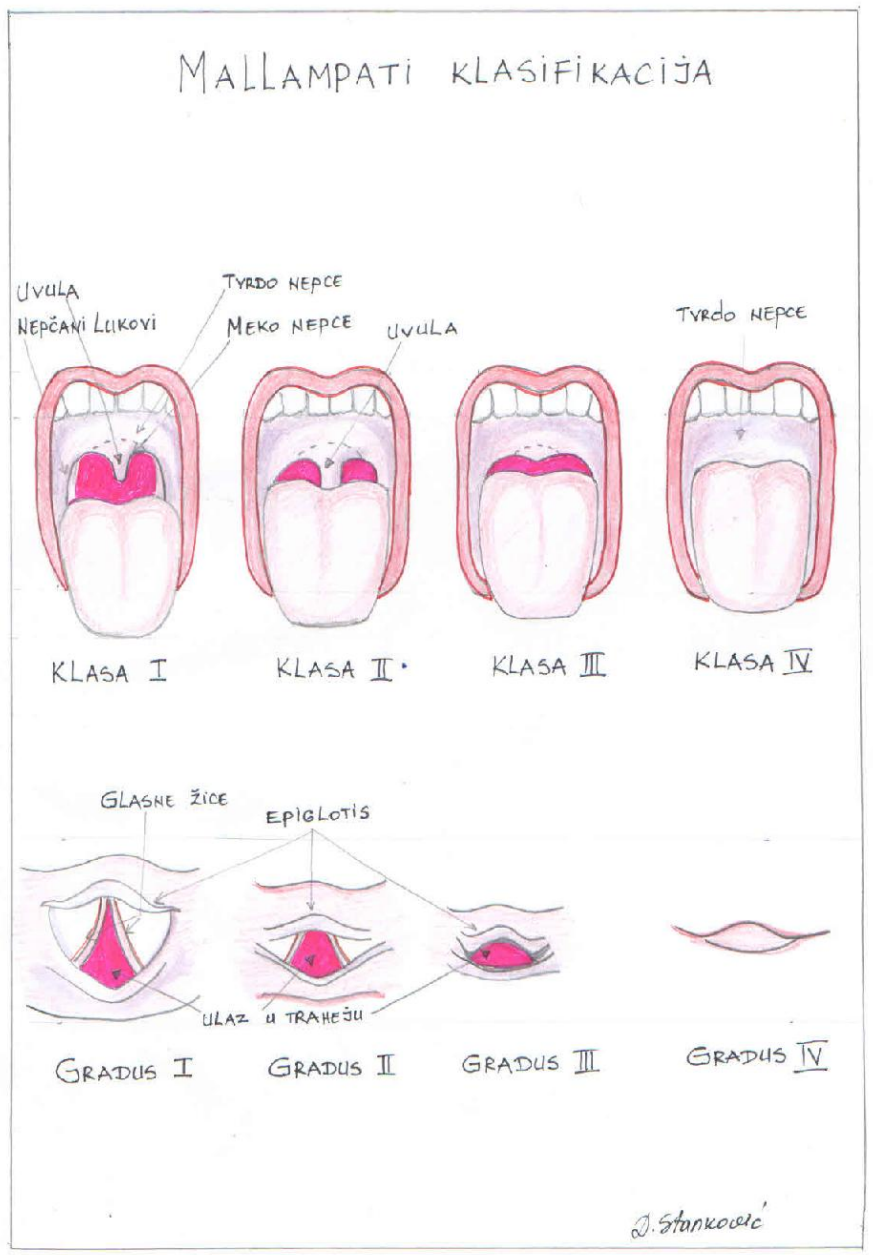

Mallampati klasifikacija se upotrebljava za procenu težine intubacije. Procena se vrši posmatranjem anatomije usne šupljine, odnosno vidljivosti uvule, tonzila i mekog nepca. Visoki Mallampati skor (klasa 3 i 4) povezan je s težom intubacijom i višom incidencom apneje. Mallampati klasifikacija je orijentaciona procena i najčešće korišćen test za procenu težine disajnog puta. Slika 1 prikazuje vidljive strukture dostupne pregledu anesteziologa, svrstane u klase, i odgovarajući vizuelni nalaz tokom laringoskopije.

Klasa I - Puna vidljivost tonzila, uvule i mekog nepca; Tokom laringoskopije se vizualizuju sve strukture larinksa: plicae vocalis, Rima glotidis, epiglotis se lako odiže

Klasa II - Vidljivost tvrdog i mekog nepca, gornjeg dela tonzila i uvule; Tokom laringoskopije vidljiv jedan deo plicae vocalis i rime glotidis.

Klasa III - Vidljivi meko i tvrdo nepce i baza uvule; Tokom laringoskopije se vizualizuje samo vrh epiglotisa i razmak između njega i zadnjeg zida larinksa. Rima glotidis i plicae vocalis nisu dostupne vizualizaciji.

Klasa IV - Vidljivo samo tvrdo nepce. Tokom laringoskopije ne vizualizuju se strukture larinksa i intubacija laringoskopom je neizvodljiva.

Najkorisnija je kombinacija testova, ne postoji idealan prediktor za procenu otežanog disajnog puta, neočekivano otežane intubacije se u praksi dešavaju s vremena na vreme.

Vodič Asocijacije za otežan vazdušni put (Slika 2.) za obezbeđenje neočekivano otežane intubacije u odraslih donosi radikalne novine, $\mathrm{i}$ po prvi put humani faktor stavlja u centar 
protokola [2]. Humani faktori se definišu kao „faktori okruženja, organizacije i posla, kao i ljudske i individualne karakteristike koje utiču na ponašanje tokom izvođenja posla na način koji može uticati na zdravlje i sigurnost pacijenta [3], i opisuju se kao „anesteziološki okviri za netehničke veštine" [4].

Slika 2. Vodič za otežanu intubaciju, 2015.

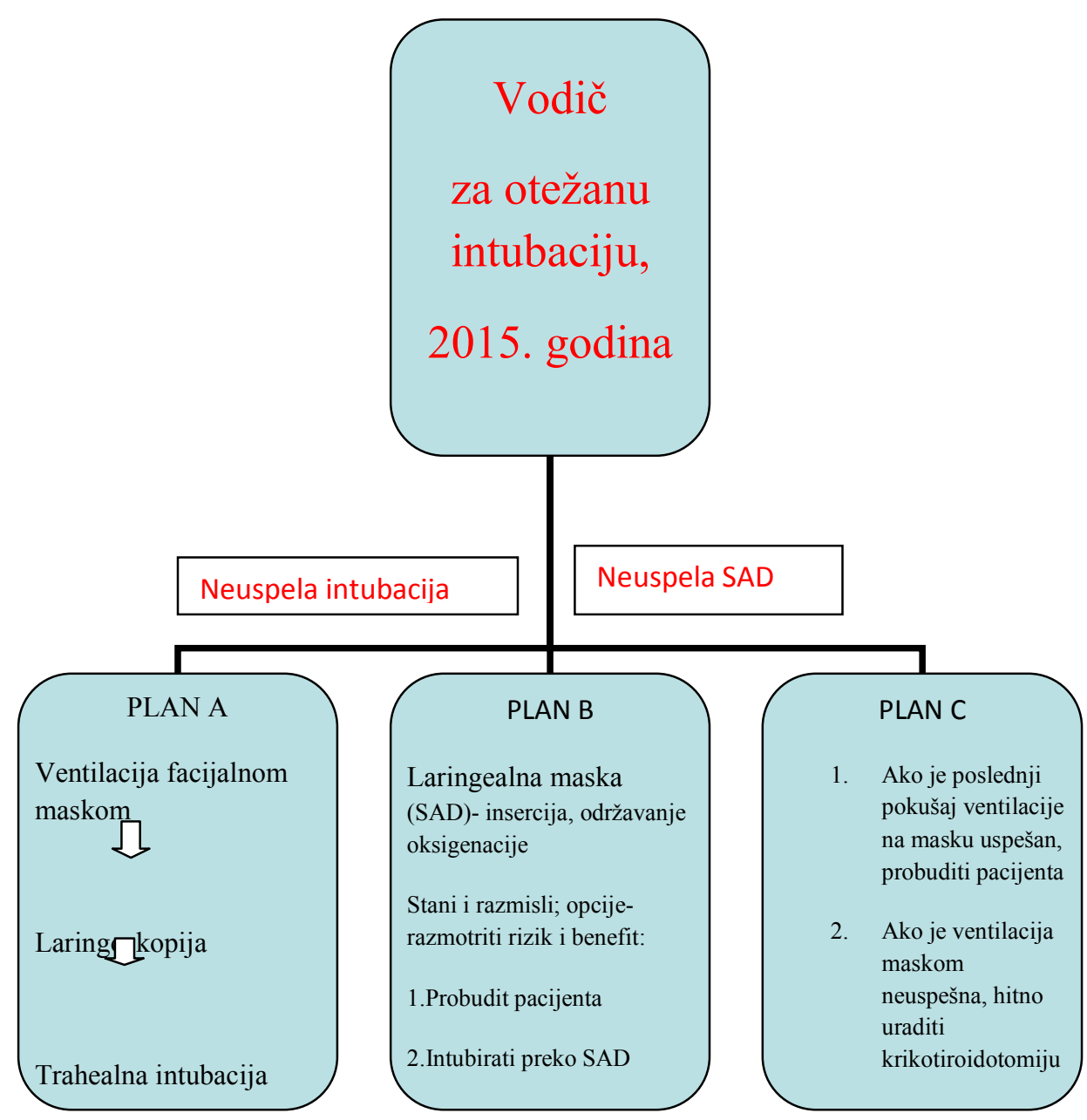

CILJ

Prikaz slučaja neanticipirano otežane intubacije, analiza postupaka i preduzetih mera.

METODE I MATERIJAL

Deskriptivna metoda prikaza slučaja, podaci iz anestezioloških karti.

Prikaz slučaja: Pacijentkinja stara 62 godine, mase $50 \mathrm{~kg}$ i visine $160 \mathrm{~cm}$, se priprema za planiranu operaciju, sa uputnom dijagnozom: Tumor ovarii dextri per magna. Laboratorijski nalazi su u granicama referentnih vrednosti. Pre dva meseca preležala pneumoniju, pušač. Ima varikozitete potkolenica umerenog stepena, granično povećane vrednosti arterijskog pritiska, ne koristi terapiju. Negira alergije na lekove i hranu. $U$ detinjstvu je imala apendektomiju. U proceni disajnog puta ima zadovoljavajuću pokretljivost vrata, tireomentalnu distancu, Mallampati 2, nije gojazna, jedino je interincizorni razmak graničnih vrednosti od oko $3 \mathrm{~cm}$. Ne anticipira se mogućnost za otežanu intubaciju. Posle premedikacije, pacijentkinja se pozicionira $u$ horizontalni položaj, uobičajen za pacijente gde 
se ne očekuje problematičan disajni put. Nakon uvoda $u$ anesteziju, ventilacija facijalnom maskom je zadovoljavajuća. Posle aplikovanog kratkodelujućeg depolarišućeg miorelaksanta pristupa se laringoskopiji. Uočava se veliki epiglotis koji je nemoguće podići, te su plicae vocalis nedostupne vizualizaciji. Vizuelni nalaz tokom laringoskopije odgovara Mallampati klasifikaciji tipa 3b. Endotrahealna intubacija je pokušana u 3 navrata. Nakon neuspeha, plasira se supraglotično sredstvo- laringealna maska.
Laringealna maska se ne pozicionira zadovoljavajuće, te se ne postiže se korektna ventilacija. Zbog insuflacije vazduha u želudac i nezadovoljavajuće ventilacije, donosi se odluka o odlaganju operativnog zahvata za nekoliko dana. Pacijentkinja se budi, diše spontano, te se smešta $\mathrm{u}$ jedinicu intenzivne nege, pod anesteziološkim nadzorom je (slika 3). Svi podaci, sa detaljnim opisom su zabeleženi u anesteziološku kartu.

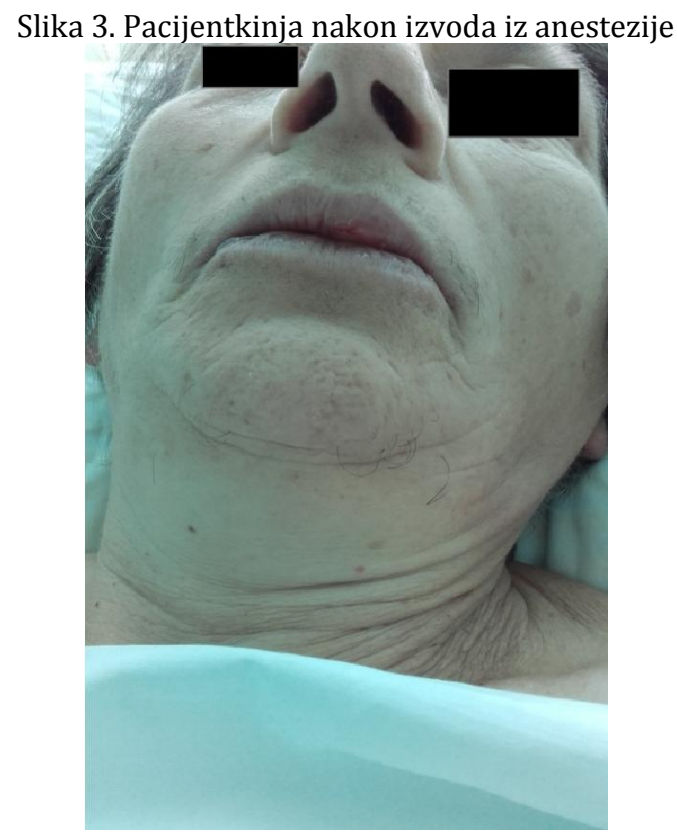

Suočen sa neanticipirano otežanom intubacijom, anesteziološki tim se detaljno priprema za odloženi operativni zahvat, i menja strategiju za obezbeđenje disajnog puta. Umesto jednog anesteziologa $\mathrm{i}$ anestetičara, tim čine dva anesteziologa i dva anestetičara. Pacijentkinja se smešta u anti-Trendeleburg položaj , pod glavu i vrat se podmeću komprese, čime se ravna osovina gornjih disajnih puteva i omogućava bolja vizualizacija anatomskih struktura. Jedan anesteziolog pristupa laringoskopiji, a drugi BURP manevrom (Backward, Upward, Rightward Pressure), modifikacijom manuelnog krikoidnog pritiska, intubatoru približava strukture larinksa, pritiskom ruke naniže,nagore i udesno, omogućava vizualizaciju i uspešnu intubaciju. Anestezija i operativni zahvat se izvode uspešno. Pacijentkinja nakon hirurške intervencije, izvoda iz anestezije i ekstubacije diše spontano. Postanestezijski i postoperativni tok protiču uredno.

$$
\text { DISKUSIJA }
$$

Neočekivano otežana intubacija koja se iskusnom anesteziologu dešava nakon decenije kliničke prakse, otvorila je sledeća pitanja: šta je anesteziološki tim mogao da uradi drugačije, jesmo li bili dovoljno pripremljeni, jesmo li ipak mogli da preveniramo neuspelu intubaciju? Vodič Asocijacije za otežani disajni put iz 2015. godine donosi radikalne novine u sagledavanju ove problematike, stavljajući humani faktor $\mathrm{u}$ centar zbivanja, i pomerajući akcenat sa opreme, na pažljivo planiranje i detaljno upoznavanje celokupnog tima sa strategijom obezbeđenja neočekivano otežanog disajnog puta [2]. Četvrti nacionalni revizorski projekat Kraljevskog koledža anesteziologa (NAP4) je nakon studije zaključio da su u krupnim komplikacijama tokom obezbeđenja disajnog puta, loši humani 
faktori participirali sa $40 \%$, a u $25 \%$ opisanih slučajeva, loši humani faktori su bili ključni za loš ishod [5].

Vodič za neočekivano otežanu intubaciju iz 2015. godine poentira sledeće nove preporuke:

\section{Planiranje}

Plan za slučaj neuspele intubacije mora unapred biti poznat i podeljen među svim članovima tima. Ceo tim mora biti familijaran sa strategijom obezbeđenja disajnog puta, posebno kod izvođenja hitnih, neodložnih kliničkih intervencija. Vodič naglašava povećanje svesti hirurga o eventualnoj potrebi da se uključe u hirurško obezbeđenje otežanog disajnog puta.
Bez obzira što je apsolutna prediktivna vrednost testova za procenu otežanog disajnog puta loša [6], ne treba smetnutu s uma da su znaci od strane anesteziologa loše interpretirani i podcenjeni.

Stopa uspešnosti intubacije tokom prvog pokušaja

Novi vodič jasno ističe značaj uspešnosti prvog pokušaja intubacije. Broj pokušaja laringoskopije se ograničava na najviše četiri. Pozicioniranje glave i vrata mora biti optimizirano pre započinjanja laringoskopije, nikako nakon prvog neuspelog pokušaja, i ova stavka koja je dugo opstala u praksi mora biti izbačena iz an estezioloških leksikona. (Slika 4).

Slika 4. Pozicioniranje glave i vrata pacijenta tokom laringoskopije

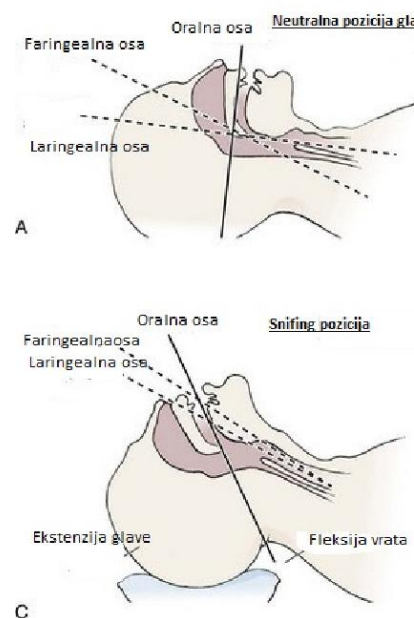

C

Objašnjenje slike 4: Da bi se intubiralo oralnim putem, potrebno je dovesti put od zuba incizora do larinksa u ravnu liniju. Ovaj put ima tri ose; oralnu, faringealnu i laringealnu.

1. U neutralnoj poziciji glave, oralna i laringealna osa se seku pod uglom od $90^{\circ}$. Da bi se intubacija uspešno izvela, ove ose je fizičkim, manuelnim manevrima neophodno poravnati, tako da se dovedu u paralelne ravni, što se izvodi pomeranjem glave i vrata pacijenta $u$ optimalnu poziciju za intubaciju.

2. U „sniffing“ poziciju se vazdušni put dovodi podmetanjem kompresa pod glavu pacijenta, tako što se odiže oko $10 \mathrm{~cm}$ od ravni na kojoj leži, bez odizanja ramenog pojasa, a onda se brada pacijenta podigne nagore i malo unazad. Tako se automatski minimalizuje rezistenca prolaska vazduha kroz vazdušne puteve. Ova pozicija je pogodna za odrasle pacijente koji nisu gojazni.

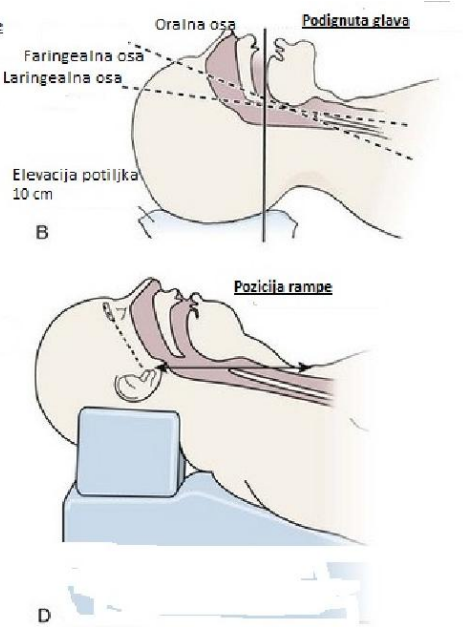

3. Pozicija sa uzdignutom glavom je slična prethodnoj poziciji, bez manevra podizanja brade.

4. Pozicija „rampe“ se koristi za gojazne pacijente i pacijente koji imaju izraženu kifozu, jer veliki anterioposteriorni dijametar grudnog koša i grudi može predstavljati smetnju tokom manevracije laringoskopom i otežati vizualizaciju struktura neophodnih za intubaciju. Rampa koja se napravi podmetanjem kompresa pod ramena pacijenta ravna vazdušni kanal sa sternalnim delom grudnog koša, i poboljšava mogućnost za otvaranje usta i vizualizaciju larinksa.

\section{Preoksigenacija}

Polazeći od zaključka da je nemoguće apsolutno predvideti otežan disajni put, onda je procesu preoksigenacije obavezno podvrgnuti sve pacijente koji će se laringoskopirati i intubirati. Videolaringoskopija 
Ako je po novom vodiču od esencijalne važnosti maksimizirati uslove da prvi pokušaj intubacije bude uspešan, onda videolaringoskop treba da postane oprema za prvu liniju izbora, u većini, ako ne i u svim trahealnim intubacijama, jer više studija dokazuje njegovu superiornost $u$ vizualizaciji glotisa [7, 8, 9].

Ventilacija facijalnom maskom

Vodič iz 2015. je eksplicitan oko sledeće nove preporuke; nakon preoksigenacije, ventilaciju facijalnom maskom, $100 \%$ kiseonikom, treba započeti što pre, odmah nakon indukcije anestezije, a pre aplikovanja miorelaksanata, „jer će anesteziolog već tada znati koliko je lako ili teško ventilirati na masku“, što će mu dati dovoljno informacija da, ukoliko je potrebno, naglo promeni odluku o strategiji i načinu obezbeđenja disajnog puta.

\section{Bužije}

Pre pojave videolaringoskopa, gumeni elastični bužije je bio glavno sredstvo za obezbeđenje otežanog disajnog puta. Nove preporuke značajno menjaju ustaljenu praksu u dva aspekta; Prvo, anestetiolog mora antacipirati razliku između 3a gradusa Mallampati klasifikacije, gde se jasno vidi razmak između epiglotisa i posteriornog zida farinksa, i 3b, gde taj razmak ne postoji. Kod pacijenata sa Mallampati gradusom 3b i 4 je nemoguće osigurati disajni put bužijeom, te od samog početka treba razmotriti obezbeđenje disajnog puta pacijentu „na budno“, pre indukcije anestezije, ili upotrebu fiberoptičkog laringoskopa. Takođe, nije svejedno kakav će se tip bužijea koristiti, i važno je da je prošao formalne testove po propisanim pravilima svetskih anestezioloških udruženja [10].

$$
\text { Brza deklaracija o neuspehu }
$$

Novi vodič je po ovom pitanju jasan; nakon četvrtog pokušaja neuspele intubacije odmah plasirati supraglotično sredstvo (SAD) za obezbeđenje vazdušnog puta (slika 5.)

Slika 5. Laringealna maska; supraglotično sredstvo za obezbeđenje vazdušnog puta

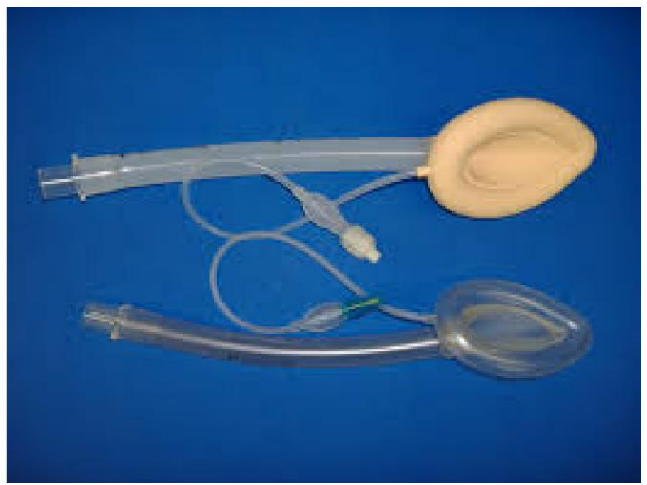

Ovakva rana odluka o odustajanju od intubacije nakon neuspeha može uticati na samopouzdanje anesteziologa, posebno kod onih kojima se $\mathrm{u}$ dugogodišnjij karijeri to nije desilo, jer se suočavaju sa priznanjem svog neuspeha. Nakon plasiranja supraglotičnog sredstva, vodič jasno nudi samo četiri opcije:

Probuditi pacijenta

Pristupiti fiberoptičkoj intubaciji

(nikako slepoj) preko SAD

Nastaviti sa hirurškom intervencijom uz upotrebu SAD za obezbeđenje vazdušnog puta Pristupiti hirurškom obezbeđenju disajnog puta - traheotomija ili krikotireoidotomija

(Slika 2.)
Vodič potpuno isključuje opciju koja se ranije koristila, da se posle plasiranja laringealne maske i ventilacije pacijenta ponovo pokuša laringoskopija, jer to može ozbiljno ugroziti život pacijenta. Od nedepolarišućih miorelaksanata, rokuronijum bromid se preporučuje kao jedina opcija izbora za sve pacijente, jer samo za njega postoji specifični medikament za reverziju neuromuskularne blokade- sugamadex. Sugamadex mora posedovati svaka bolnica, i mora biti lako dostupan personalu.

Kontinuirani godišnji treninzi svih članova anesteziološke ekipe, kontinuirana edukacija i usvajanje novih znanja i veština moraju postati obavezni.

Više je prikaza slučajeva u literaturi na temu neočekivano otežane intubacije. Svaki od nijh je 
specifičan, kako u tumačenju razloga zašto je došlo do neprepoznavanja predilekcije za otežanu intubaciju, tako i u načinu rešavanja ove probematike. Nishimori i saradnici [11] opisuju slučaj neprepoznate orofaringealne stenoze kod pacijenta koji je imao tonzilektomiju i komplikacije nakon operacije. Slučaj je ostao neprepoznat usled manjkavosti u uzimanju anamnestičkih podataka, zbog postojanja jezičke barijere između pacijenta i lekara. Slučaj je rešen tako što je nakon neuspele intubacije pacijent probuđen i operacija odložena. Nakon pregleda specijaliste otorinolaringologije i opisa i lokalizacije stenoze, izvedena je intubacija fiberoptičkom bronhoskopom, uz plasiranje endotrahealnog tubusa manjeg dijametra. Ortiz i saradnici [12] opisuju slučaj neočekivano otežane intubacije koji je rešen insercijom laringealne maske, potom plasiranjem aintree intubacionog katetera kroz nju, koji istovremeno omogućava i ventilaciju, zatom sklanjanjem maske i upotrebom fiberoptičkog bronhoskopa i intubacijom uz pomoć bronhoskopa. Ovi autori preporučuju aintree kateter kao odlično sredstvo u slučajevima neočekivano otežane intubacije.

\section{ZAKLJUČAK}

Humani faktori su od krucijalnog značaja za uspešno obezbeđenje neanticipiranog otežanog vazdušnog puta. Pažljivo prethodno planiranje i priprema su ključni za uspeh, sa izabranom logičnom strategijom i preduzetim merama od strane iskusnog anesteziologa. Neophodno je detaljno informisanje i sastanak svih članova an esteziološkog i operacionog tima, da bi se podelile instrukcije u pripremi za predstojeći zadatak. Pribranost $\mathrm{u}$ datoj situaciji je vitalna, da bi se greške ispravile ili izbegle. Disciplinovana komunikacija i pažljivo liderstvo anesteziologa obezbeđuju dobru dinamiku u radu tima. Sastanak tima omogućava članovima da osveste svoju pojedinačnu ulogu i odgovornost, kao i ideju o tome da smo svi „na istoj strani“, i delamo u istom interesu. Jasnoća u komunikaciji i liderstvo odgovornog anesteziologa pomažu $u$ pravovremenom donošenju odgovarajućih odluka.

Oprema za otežanu intubaciju mora biti lako dostupna svim članovima tima. Opremu treba obnavljati i pratiti trendove. Fiberoptički bronhoskop postaje neophodan, ali ga nažalost mnoge ustanove ne poseduju.
Sve poteškoće i eventualne komplikacije tokom obezbeđenja vazdušnog puta, kao i način rešavanja, detaljno zabeležiti $u$ medicinsku dokumentaciju, što je od ogromnog značaja za anesteziologa i pacijenta pri eventualnom sledećem operativnom zahvatu.

Kontinuirani godišnji treninzi svih članova anesteziološke ekipe, kontinuirana edukacija i usvajanje novih znanja i veština moraju postati obavezni.

\section{LITERATURA}

1. Apfelbaum JL, Hagberg CA, Caplan RA, Blitt CD, Connis RT. Practice guidelines for management of the difficult airway: an updated report by the American Society of Anesthesiologists Task Force on Management of the Difficult Airway. Anesthesiology 2013; 118(2):251270.

2. Frerk C, Mitchell VS, McNarry AF, Mendonca C, Bhagrath R, Patel A, et al, Difficult Airway Society intubation guidelines working group. Difficult Airway Society 2015 guidelines for management of unanticipated difficult intubation in adults. British Journal of Anaesthesia 2015; 115 (6): 827-848.

3. Health and Safety Executive. Reducing Error and Influencing Behaviour. HSG48. London: HSE books; 1999.P. 2-2.

4. Fletcher GC, Mc George P, Flin RH et al. The role of nontechnical skills in anaesthesia: a review of current literature. Br J Anaesth 2002; 88: 418-29.

5. Shaw J, Frerk C, Russell J. A commentary on human factors aspects of cases reported to NAP 4. In: Cook TM, Woodall N, Frerk C, eds. Fourth National Audit Project of the Royal College of Anaesthetists and Difficult Airway Society. Major Complications of Airway Management in the United Kingdom. Report and Findings, Chapter 24. London: Royal College of Anaesthetists; 2011. P. 193201.

6. Yentis SM. Predicting difficult intubation-worthwhile exercise or pointless ritual? Anaesthesia 2002; 57: 105-9.

7. Van Zundert A, Pieters B, Doerges V, Gatt S Videolaryngoscopy allows a better view of the pharynx and larynx than classic laryngoscopy. British Journal of Anaesthesia 2012; 109: 1014-5.

8. Li RP, Xue FS, Liu GP, Sun C. Using the C-MAC videolaryngoscope as a first-line device for out-ofhospital emergency intubation. European Journal of Anaesthesiology 2016; 33: 61.

9. Healy DW, Maties O, Hovord D, Kheterpal S. A systematic review of the role of videolaryngoscopy in successful orotracheal intubation. BMC Anesthesiology 2012; 12: 32.

10. Pandit JJ, Popat MT, Cook TM, et al. The Difficult Airway Society 'ADEPT'guidance on selecting airway devices: the basis of a strategy for equipment evaluation. Anaesthesia 2011; 66: 726-37.

11. Nishimori et al. Unanticipated difficult airway due to undiagnosed oropharyngeal stenosis: a case report JA Clinical Reports, (2016) 2:10

12. Ortiz J, Broussard T M and Wali A: An unexpected case of a difficult airway secured using an aintree intubating catheter for intermittent oxygenation and exchange of a laryngeal mask airway for an endotracheal tube. Journal of Anesthesiology and Clinical Science 2013, 2:4. 